\title{
Transboundary water management and security in Central Asia ${ }^{1}$
}

\author{
Stuart Horsman
}

Central Asia is subject to a number of major environmental concerns, including the desiccation of the Aral Sea, the depletion and degradation of river and irrigation waters, and the consequences of Soviet and Chinese nuclear weapons testing at Semipalatinsk and Lop Nor, respectively. Riverine water, particularly when linked with irrigated land, is perhaps the only one of these environmental issues that demonstrates a "probable linkage between environmental degradation and the outbreak of violent civil or interstate conflict'. ${ }^{2}$ This proposition reflects current research suggesting that globally fresh water is the renewable resource most likely to be a source of conflict in the near future. ${ }^{3}$

Historically water provided a cultural, economic and geographical focus for Central Asia. The khanates' political culture, including deferential collectivism, was associated with water scarcity and the organisational requirements of the construction and maintenance of irrigation systems. ${ }^{4}$ Irrigation was 'one of the principle functions of state power' ${ }^{5}$ Conflict in the region was often linked to or affected water resources. ${ }^{6}$ Tsarist and Soviet expansion of irrigation networks in the region heightened water's strategic importance, illustrated by the Bolsheviks' attempt to pacify the Ferghana Valley in the 1920 s and by the national delimitation process of $1924-36 .{ }^{7}$ During the late Soviet period, the Aral Sea and related irrigation crises provoked friction between Moscow and environmental and nationalist critics in Central Asia, and Uzbekistan in particular. ${ }^{8}$ Competition for land and water was also cited as a contributory, if not the primary, cause of interethnic violence in the Batken-Isfara, Osh and Samarkand regions. ${ }^{9}$ Since the Soviet Union's collapse, a number of academics and politicians have cited a relationship between Central Asia's water crisis and regional stability. ${ }^{10}$ The recent extended drought in the region has renewed concerns about this dynamic. As well as the Aral Sea basin issue, another transboundary river dispute is emerging between China and Kazakhstan. 
While riverine water is the environmental issue most liable to lead to war in the region, such an outcome remains improbable for a number of reasons, some related to water and others not. Water's security implications principally fall within the wider conceptualisation of security - as an indirect or contributory cause to instability. Poor water management affects diplomatic relations, economic development, public health and access to land. Thus, while interstate war directly associated with water disputes is not likely to take place in the near future, it is expedient to address Central Asia's water problem. There is a broad consensus that interstate cooperation is required if the problem is to be managed properly. Consequently, a number of international institutions, which range from the regional to the global, have been involved in addressing the issue. These represent a breadth of interests and bailiwicks, ranging from traditional and non-traditional security to economic development and integration to environmental sustainability.

\section{Transboundary water resources in Central Asia}

The 1.8 million $\mathrm{km}^{2}$ Aral Sea basin encompasses all of Kyrgyzstan, Tajikistan, Turkmenistan and Uzbekistan, the two Kazakhstani provinces of Qyzylorda and Southern Kazakhstan, 40 per cent of Afghanistan and a small area of Iran. The basin supports 75 per cent of Central Asia's total population and contains 90 per cent of the region's surface water. Two rivers, the Amu Darya and Syr Darya, both of which drain into the Aral Sea, dominate the region. The former rises in the Pamir mountains and flows through Tajikistan, Uzbekistan and Turkmenistan before entering the sea. The Syr Darya's source is the Naryn River in Kyrgyzstan, and its subsequent route to the Aral Sea travels through Tajikistan, Uzbekistan and Kazakhstan.

Since the 1950s, the rapid expansion in irrigated agriculture has reduced the rivers' combined flow into the Aral Sea by 90 per cent and has resulted in an adverse environmental impact on the region. Between 1960 and 1998 , the sea's volume and area declined by approximately 80 per cent and 50 per cent respectively. It has now divided into a small northern and larger southern section. ${ }^{11}$ Riverine water in Central Asia is economically significant, politically sensitive and overutilised. The present water crisis can be attributed to a large extent to two Soviet-era polices: the establishment and demarcation of the five Soviet Socialist Republics (SSRs); and the rapid expansion of irrigation agriculture since the 1950s. Dams constructed upstream, in the Kyrgyz and Tajik SSRs in particular, stored water for irrigation and also hydroelectric production (HEP), which accounted for $35 \%$ of Central Asia's energy by the early 1990s. ${ }^{12}$ These policies and processes created a regional economic complex, but also led to intra-regional problems and tensions.

The misallocation and overallocation of water, its economic significance and competing demands are expected to increase in the near future. Over 50 
per cent of water supplies for Kyrgyzstan, Turkmenistan, Uzbekistan and the two southern Kazakhstani provinces are extra-republican in source. ${ }^{13}$ While this in itself does not indicate an intractable source of tension, these supplies are overutilised and matters are further complicated by charges of inequitable water allocations. Under the existing water agreements the three downstream states (Kazakhstan, Turkmenistan and Uzbekistan) receive 73 per cent of total withdrawals from the Aral Sea Basin. ${ }^{14}$ This contrasts with upstream Kyrgyzstan and Tajikistan. These two countries, the source of 90 per cent of all available waters, are allocated only 5 per cent and 11 per cent, respectively. ${ }^{15}$

These allocation problems are significant because of the importance of riverine water to agriculture, an important sector of these nations' economy. Irrigated land produces 90 per cent of the region's crops. Cotton, the single most important irrigation crop, underpins Uzbekistan and Turkmenistan's economies. It provides 30 per cent of Uzbekistan's gross domestic product (GDP), 35 per cent of its employment and 27.4 per cent of exports. Similarly, over 50 per cent of both Kyrgyzstan's and Tajikistan's electricity production is generated using HEP. ${ }^{16}$

Demographic pressures further increase the contested nature of the region's water. Between 1959 and 1989, the population of the basin states increased by 140 per cent. ${ }^{17}$ It is expected that it will increase by a third again by $2020 .{ }^{18}$ Fifty per cent of the region's population lives in 20 per cent of its area - the Ferghana Valley, Lower Zeravshan and Tashkent-Khujand Corridor. ${ }^{19}$ These are the prime irrigated areas, emphasising the relationship between population pressures and competition for limited access to water and fertile land, as was evident in the Kyrgyz-Tajik violence, over land and water, during the 1980 s. $^{20}$

These problems existed in the Soviet period, but were manageable while the Soviet Union remained intact. The region's water resources were controlled by a unified system, the Ministry of Land Reclamation and Water Resources, based in Moscow. ${ }^{21}$ While disagreements existed, there was a single and final arbiter - Moscow. ${ }^{22}$ Downstream Kazakh, Turkmen and Uzbek SSRs were allocated the majority of the waters for irrigation, while the upstream Kyrgyz and Tajik SSRs were compensated by energy supplies from their neighbours. With the break up of the USSR, '[a]ll of a sudden, a very complex water management problem became a very complex transboundary water management problem'. ${ }^{23}$ In other water-scarce areas the water problem and its management have gradually evolved in tandem with the development of relations between the riparians. This has not been the case in Central Asia, where the states have been rapidly forced to assume responsibility and develop management strategies.

Another distinct transboundary water management issue of regional significance is emerging between China and Kazakhstan. The two states share 24 rivers, the key ones being the Ili and Irtysh, both of which rise in 
China. ${ }^{24}$ Eighty per cent of Kazakhstan's Ili Valley water originates in China, while the Irtysh supplies the industrial regions of central and eastern Kazakhstan. ${ }^{25}$ China plans to extract water from the Ili and Irtysh rivers for Urumchi and oilfield developments in the Xinjiang Uighur Autonomous Region. ${ }^{26}$ The proposal has both economic and political objectives - to stimulate the economy of Xinjiang, to raise living standards, and to erode support for Uighur irredentism. As well as the constraints on Kazakhstan's economic growth and living standards, China's proposals have broader environmental implications. These include the increased salinisation and shallowing of these rivers as well as the Balkhash and Zaisan lakes, and adverse microclimate changes, problems already evident around the Aral Sea.

\section{The regional response: institutional innovation}

The most fundamental and important function that an international institution can undertake is actually managing and allocating the region's water resources. The Central Asian leaderships quickly acknowledged the need for indigenous responsibility with the signing of the 1992 Almaty Agreement. The agreement stated that 'only [through] unification and joint coordination of action' could the region's water crisis be managed effectively. ${ }^{27}$ Under the agreement, the states agreed to retain their Soviet-period water allocations and refrain from projects infringing on other states, and promised an open exchange of information. ${ }^{28}$ From this auspicious beginning the republics initiated a plethora of agreements and institutional structures. These included the Interstate Commission on Water Coordination (ICWC), the Amu Darya and Syr Darya Basin Management Authorities (BVOs) subordinated to the ICWC, the Interstate Council on Problems of the Aral Sea Basin (ICAS), and the International Fund for the Aral Sea (IFAS).

Institutional reforms in 1997 merged the ICWC and the ICAS, with the former subsumed by the later. It was hoped that the merger would simplify administrative procedures and resolve duplication of effort and bureaucratic inertia. ${ }^{29}$ This step was a positive indication of the states' awareness of the seriousness of the crisis and the need to coordinate their response more effectively. IFAS's responsibilities after 1997 included deciding water allocations among the republics and the Aral Sea, overseeing the 'regulation, use and the protection of water courses', acting as a conduit for the states to give notification of intentions to act, and the avoidance of 'disputes before they arise'. ${ }^{30}$ The IFAS increased its role further when it was provided with the managerial responsibility of Phase Two of the Aral Sea Basin Program (ASBP). The World Bank had played a more prominent managerial role in Phase One of the ASBP, a project discussed in more detail later in this chapter. ${ }^{31}$

The Central Asian presidents continue to reiterate their commitment to cooperative water management via the IFAS, other regional organisations 
and regional summits. Between March 1998 and January 2000, six framework agreements and nine annual operational agreements, including waterenergy sharing agreements, were signed between different Syr Dayra states. $^{32}$ Similarly, a joint presidential proposal for further intergovernmental agreements on water use was proposed at the Central Asian Economic Union's (CAEU) June 2000 meeting. ${ }^{33}$ Likewise the December 2001 Declaration of the Central Asian Cooperation Organisation (CAC), the CAEU's successor, stated that the 'heads of state are convinced that coordinated and agreed actions in the sphere of rational and mutually advantageous use of water facilities and hydro-energy resources based on the principles and norms of international law will serve as a basis for effective use of the existing agricultural and energy potential of the states' ${ }^{34}$ The CAC has one key attribute, which encourages such an optimistic assessment - its membership. It includes the four Syr Darya riparians and avoids the more difficult Amu Darya basin issue and the region's most difficult interlocutor, Turkmenistan.

Regional bodies, however, have been found wanting. None, and in particular not the IFAS, has established an effective institutional framework for regulating regional water disputes. As one commentator recently stated, there are 'too many intergovernmental agreements [which] remain just words on a piece of paper'. ${ }^{35}$ The principle cause of this ineffectiveness has been the organisation's key stakeholders. Political differences, lack of political and financial commitment, and failure to implement agreements have weakened these bodies. Initially, it was proposed that the IFAS would rely on contributions from the member states of 1 per cent of their individual gross national products (GNPs), with additional international donations. ${ }^{36}$ The IFAS then reduced the level of contributions to 0.3 per cent for Kazakhstan, Turkmenistan and Uzbekistan, and 0.1 per cent for Kyrgyzstan and Tajikistan. Despite this revision, the majority of its member-states have been unable or unwilling to pay their agreed contributions. ${ }^{37}$ More generally, the Central Asian government's political and financial commitment to the IFAS and other regional initiatives has been poor, Kazakhstan being the exception. Although the IFAS has been underfunded, Kazakhstan, Turkmenistan and Uzbekistan have spent in excess of $\$ 650$ million on projects within their own territory related to the Aral Sea. ${ }^{38}$ The IFAS has been unable to develop an institutional identity or authority distinct from its members.

In an effort to provide some sense of permanency and consistency, the IFAS's Scientific Commission of the ICWC, which prepares the data for the annual irrigation plans, is now permanently based in Tashkent. This basing decision, however, caused difficulties when the ICWC refused to provide Turkmenistan, when it was the IFAS chair, with relevant hydrological data. As a result of such difficulties the IFAS's effectiveness has been limited. Similarly, the CAC's ambitious objectives are not matched by reality. Its goal of a single economic space by 2002, for example, did not materialise and its 
members have failed to implement the institution's decisions. In the long term the CAC may be the basis for an effective and indigenous organisation, but the present prognosis is not encouraging.

The republics and international donor community have increasingly acknowledged the nexus between energy supplies and water supplies formed by the Soviet management of regional waters. Kazakhstan, Kyrgyzstan, Tajikistan and Uzbekistan have initiated a number of relevant agreements, with encouragement from the EU-TACIS and the United States Agency for International Development. ${ }^{39}$ The most promising of these initiatives is the Council of the Central Asian Energy System, established in August 2001. However, it remains a fragile structure and the issue is still as intractable as ever. The states have frequently failed to honour agreements - suspending supplies of water or energy, or not paying debts on time. Kyrgyzstan, for example, was still awaiting the delivery of 30,000 tonnes of coal from the 2000 agreement in April 2001. Similarly, Uzbekistan has sporadically cut gas deliveries to Kyrgyzstan because of Bishkek's energy debts and possibly as a means of political leverage. ${ }^{40}$ A Kyrgyzstan-Uzbekistan energy-water agreement collapsed soon after it was signed in December 2000. Kyrgyzstan was forced to release waters for HEP, which were allocated for Uzbekistan's summer irrigation requirements, because the latter had cut gas supplies. A new agreement was signed in March 2001. Consequently, Uzbekistan may have received only a third of the water it should have been allocated. Tashkent estimated that this cost it $\$ 400$ million in lost agricultural revenue. ${ }^{41}$ Similar difficulties were reported in early $2002 .{ }^{42}$

The potential disputes over the Ili and Irtysh have attracted less international involvement. The most relevant organisation in this context is the SCO. Kazakhstan has attempted to draw the SCO into the problematic, with mixed results. At the 2001 SCO Shanghai Summit, President Nazarbaev stated that there is a need for cooperation in 'environmental-related interaction, first of all, in the border zones ... There are such issues as transboundary rivers [that] both sides are trying to resolve. In some cases, it would be preferable to conduct multilateral negotiations in the context of the Shanghai Cooperation Oganisation. ${ }^{43}$ China subsequently allowed Kazakhstan to survey the upper reaches of the Irtysh. ${ }^{44}$ In fact, Amanbek Ramazanov, the chair of Kazakhstan's Water Resources Committee, suggested the preceding summit had provided a suitable opportunity for progress on the negotiations. ${ }^{45}$

In reality, the SCO has so far provided a limited forum to deal with transboundary water negotiations. The negotiations on the rivers remain bilateral in nature. ${ }^{46}$ The Declaration of the SCO does state that the organisation aims to encourage 'further effective cooperation in politics, economy, science and technology, culture, education, energy, transportation, environmental protection and other fields' ${ }^{47}$ However, the fundamental interests of the SCO and in particular its most powerful members, China, Russia 
and Uzbekistan, are firmly linked to traditional security interests. This confluence of interests within the SCO reflects a common preoccupation with irredentism, terrorism and extremism. These three states also view and respond to new security challenges in a traditional manner. As a result, only modest expectations can be placed on the SCO's role in and effective management of regional water management issues.

\section{The extra-regional response}

Given the fact that Central Asian states have had only ten years to assume managerial responsibility and develop the institutional structures, it is understandable that indigenous institutions have not been entirely successful. In this milieu a number of extra-regional organisations have become involved in regional water issues. The principal role that these institutions can play is in technical assistance and institution building/capacity development.

The awareness in the donor community of the need for creating and strengthening an institutional framework for regional cooperation, based on a clear set of structures and institutional framework, has led to some successes. Both the ICAS and the IFAS were established under international donor pressure to improve regional cooperation on water management policies. ${ }^{48}$ The World Bank, United Nations Development Program (UNDP) and United Nations Environmental Program have been involved with the Central Asian states in the ASBP. The three-phase, 20-year ASBP aims to stabilise and rehabilitate the environmental situation and develop the region's institutional capacity in order to implement the remedial work. ${ }^{49} \mathrm{In}$ Phase One, the World Bank temporarily moved out of its traditional financial and technical roles to become an active participant in related negotiations. ${ }^{50}$ By Phase Two, however, the World Bank had returned to its more traditional role, focusing upon financial assistance and support of regional management and capacity building. Both the UNDP and EU-TACIS's Water Resources Management and Agricultural Production (WARMAP) have assisted in capacity building. ${ }^{51}$ WARMAP has also sought to enhance water management strategies and information sharing. ${ }^{52}$

Another area in which extra-regional institutions have offered assistance is the application and implementation of international water law. This effort has had limited success to date. While water management agreements continue to be signed, none of the IFAS ones have been accorded the status of international law, as is the norm for other treaty-based river basin commissions. Neither of the BVOs is recognised by national legislatures and therefore they lack authority. ${ }^{53}$ Similarly Eric Sievers reports that China has contravened both international law and bilateral agreements: in particular it has failed to notify and consult Kazakhstan on its intentions or provide environmental impact assessments. ${ }^{54}$ Kazakhstan is the only Central Asian 
state to have acceded to the Helsinki Convention on the Protection and Use of Transboundary Watercourses and International Lakes. ${ }^{55}$ However indirectly, international water law has penetrated the debate. The World Bank, for example, has supported only projects that do not contravene international water law principles. ${ }^{56}$ WARMAP has likwise been involved in this sphere: 'Unlike the other aid projects with a technical focus, WARMAP had a specific legal and institutional agenda to create a framework for water sharing based on legal principles in accordance with the Helsinki Rules and International Law Commission recommendations'. ${ }^{57}$

Extra-regional organisations have played an important role in providing financial assistance to the region. The World Bank's Vice President for Europe and Central Asia, Johannes Linn, argues that the World Bank has two instruments, financial assistance and the appropriating of water resources, that can solve the Kazakhstan-Kyrgyzstan 'water problem' ${ }^{58}$ As Philip Micklin notes, although it is difficult to record the actual levels of foreign financial assistance, the World Bank had loans and credits of $\$ 605$ million to the Central Asian states in $2000 .{ }^{59}$ However, the relationship between the regional governments and extra-regional donors has been problematic. The regional governments' expectations that the international donor community would provide large-scale and unconditional financial assistance because the Aral Sea crisis is a 'global concern' is unrealistic. Conditionality and transparency have posed difficulties between the two parties, as have different expectations about the pace of related economic, environmental and management reforms. During 2001, these differences emerged when Uzbekistan sought financial assistance from the World Bank and United Nations (UN) as well as other donors to address the consequences of the ongoing drought. ${ }^{60}$ The donor community was initially reluctant to offer further money - Tashkent had failed to implement any remedial policies, had in fact further exacerbated the drought by its water management and agricultural policies, and failed to account properly for previous loans.

While the potential for water-related conflict in Central Asia exists, water is unlikely to provoke interstate conflict by itself. Water-related issues remain none the less highly disputed and are discussed in a tense if not antagonistic manner. Water has also at times been incorporated, at least rhetorically, into the traditional security sphere. The rebel Tajik commander Mahmud Khudaberdiyev threatened to destroy a dam during his November 1998 insurrection. ${ }^{61}$ There were also reports that groups in Tajikistan once discussed the idea of using the Syr Darya as 'an offensive weapon in any territorial dispute with Uzbekistan', and that Uzbekistan would threaten to use military force to seize the Toktogul Dam if Kyrgyzstan attempted to alter the existing distribution policy. ${ }^{62}$ It is unclear whether any of these threats had any substance. They do indicate a regional political atmosphere from which confidence and cooperation are absent. In such a milieu, international institutions can provide essential assistance in conflict prevention and 
confidence building. There are a number of security-orientated organisations which should be able to provide this function in this region, most notably the UN, the OSCE and the SCO.

The OSCE's inclusive Eurasian membership, comprehensive security concept (which includes an environmental dimension) and cooperative approach to resolving security problems make it one of the most relevant organisations in this context. ${ }^{63}$ It is not surprising, therefore, that the 'Central Asian republics have called upon the OSCE to assist in addressing the environmental issues of security in the region, particularly the question of water resources'. ${ }^{64}$ As a result, the OSCE has focused on the promotion of consensus building and the support for negotiated and institutional approaches to water management, which the OSCE regards as 'important instruments for preventing potential conflict'. ${ }^{65}$ Wilhelm Hoynck, special representative of the chairman-in-office for Central Asia, recently highlighted this conflict-prevention role of the OSCE: 'Central Asia is a region with a high potential for problems and also conflicts. But at this point ... is not a crisis region. And here we have a challenge for the international community to deal with a situation which is really a task of crisis prevention' (italics added). ${ }^{66}$ The Central Asian states and the OSCE have had a difficult relationship, in particular in relation to the differing priorities over which of the OSCE's three dimensions of security should take priority in the region. The OSCE's Water Initiative, an attempt to encourage dialogue and cooperation, failed because of competing attitudes towards external intervention and the value of bilateral or multilateral diplomacy. Similar problems have affected the other water management scenario under discussion, the Sino-Kazakh waterways. The SCO's original raison d'être was confidence building and it successfully produced a multilateral agreement on military reductions along the joint Sino-former Soviet Union borders. ${ }^{67}$ However, as noted previously, the SCO has not been able to provide more than an informal forum and indirect confidence-building measures on water issues.

Institutional involvement can also help define the norms of debate and behaviour, and indicate what is environmentally, financially or technically feasible. In 2001 there were reports that President Karimov had proposed the revival of the Sibaral water diversion scheme. This plan was met with broad international disapproval. The World Bank refused to fund even preliminary analysis of the scheme. ${ }^{68}$ Despite significant financial resources and global credibility, the leverage that international institutions have on encouraging cooperative and sustainable management structures should not be overestimated.

\section{Understanding the limitations of institutions}

Regional and international organisations have had mixed success in managing Central Asia's water. Cooperation on water issues is attainable as long as 
other, more deep-seated political differences can be managed. To a great extent the failings in regional water management are indicative of the broader political context. While interstate conflict or major diplomatic disputes have been avoided, it is not certain whether institutional bodies, within and outside of the region, have played a significant role in deterring them. Nor have there been significant improvements in water management or environmental protection - key objectives of the many institutions involved. As Daniel Bedford and Philip Micklin independently argue, regional institutional arrangements, such as the IFAS, could play a significant role in water management, but weak political commitment and cooperation, and financial and legal constraints, have hamstrung them. ${ }^{69}$ Newly found and jealously guarded state sovereignty, lack of trust, of confidence and of compromise, unequal economic and political relationships, poor economic development, and the legacy of Soviet attitudes, infrastructure and norms have all hindered the development of regional cooperation. Political and personal rivalries between the Central Asian leaderships also weaken the potential for regional cooperation. For example, Niyazov's antipathy to Karimov's appointment as head of the IFAS marred the organisation's February 1997 summit meeting. ${ }^{70}$ Problems and misunderstanding with and within the international donor community have also complicated the situation.

It is understandable that the region's governments have been keen to protect and promote their state sovereignty. However, this protection of sovereignty is also indicative of regional political thinking, in which policymakers have at times applied nationalist, protectionist and 'zero-sum' calculi to the problem. For Turkmenistan and Uzbekistan, this feeds into their opposition to revisions of water allocations and the preference for bilateral diplomacy over multilateral engagement. Turkmenistan is the most obvious proponent of this approach. Despite the evident need for interstate cooperation, President Niyazov has stated that multilateral organisations 'shall not infringe upon [Turkmenistan's] sovereignty'. ${ }^{71}$ When invited by the OSCE to participate in collective water discussions, both Asgabat and Tashkent declared that they favoured bilateral approaches. ${ }^{72}$ Uzbekistan's refusal to participate in the multilateral discussions was accompanied by the statement that Uzbekistan had a thousand years of resolving its own water problems. ${ }^{73}$ Similarly Henning places China's behaviour in the Irtysh scenario within Asia's broader and bleak environmental security dynamic. Beijing's assertive water policy is indicative of a trend in Asia, where states are keen to ensure their national water supplies, often to the detriment of the stability of other states and the region. ${ }^{74}$ This attitude was also evident in Asgabat's redefining of the Kara Kum Canal as a river and entirely on its own territory. In Asgabat's view, this meant that the related allocation and management issues would not require interstate consultation. ${ }^{75}$

Unequal power relationships pervade the ongoing water disputes. There 
are in essence conflict of interests between 'status quo' and 'revisionist' states. The former have the most to lose if allocations are renegotiated, while multilateral negotiations provide the best option for the latter to reverse what they perceive as inequitable quotas. ${ }^{76}$ This dynamic is evident in the Kazakhstan/Uzbekistan/Turkmenistan-Kyrgyzstan/Tajikistan, Turkmenistan-Uzbekistan and China-Kazakhstan cases.

Most of the Central Asian leaders lack a genuine commitment to finding a viable solution to the regional water crisis. The lack of commitment is evident in the republics' limited support of the relevant organisations. It is also noticeable in a pervasive attitude within the region that because the problem is of Soviet origin and of considerable magnitude, the present governments should not be expected to shoulder the burden on their own. ${ }^{77}$ Unless regional ownership and initiative are enhanced it is difficult to see how the problem will be resolved or why external actors should be seriously involved. Economic policies and priorities have hampered cooperative water management. The continuation of Soviet-style and unsustainable environmental and economic practices has been a major impediment for Turkmenistan and Uzbekistan. Admittedly, there has been a modest decline in acreage under cotton since 1991, and a corresponding expansion in less 'water-thirsty' grain production. This change in the composition of crops under cultivation has been undertaken principally to promote national food self-sufficiency, rather than to reduce water consumption and forestall an ecological disaster.

During 2001, the fourth year of a regional drought, both Turkmenistan and Uzbekistan sought to find new water sources, drilling new boreholes, for example, rather than reduce state-planned targets for cotton and grain production. Similarly both Turkmenistan's planned Lake of the Golden Age and the reported revival in the Sibaral scheme suggest outdated and unsustainable developmental and environmental thinking. ${ }^{78}$ After a decade of independence, an Uzbekistani water expert could state: 'the re-routing of ObIrtish [sic] appears to be the only tangible solution to the ecological and other problems caused by the drying of the Aral Sea.... [T]he international community could conceivably provide funding to support a project ... rerouting the Ob-Irtish to [the] Aral Sea'. ${ }^{79}$ This statement suggests that international institutions and norms on water management may not have penetrated the regional understanding on the water crisis as deeply as many advocates have hoped or suggested.

The divisions between the republics' individual economic priorities, between HEP and irrigation requirements, and between HEP-reliant states and hydrocarbon producers have also weakened institutional agreements and management. The fragile nature of the recent energy-water transfer agreements demonstrates that while the republics are aware of the potentially symbiotic relationship between water and energy, they have not found a robust or mutually beneficial mechanism to regulate this dynamic. As a 
result water remains a scarce, strategic resource which the states find difficult to compromise on. Without a shift in economic thinking and priorities, a viable compromise over the distribution of water among the riparian states will remain elusive.

\section{Management prospects and implications for Eurasian security}

Water remains a contested and strategic asset for the four countries of the Aral Sea Basin and may become so between China and Kazakhstan in the near future. How far water-related conflict is likely in the future is difficult to gauge. International evidence, particularly from the Middle East, suggests that interstate water-related conflict is the exception rather than the rule. ${ }^{80}$ It is fortunate that water rarely results in interstate violence. Demand for water is, however, intense and predicted to increase in the near future. Moreover, rising demand is accompanied by a number of negative political factors: poor collective management, proposals for further water extraction, tension in interstate relations, bellicose diplomatic rhetoric, and sporadic but low-level violence at the communal level.

The countries of the Aral Sea Basin do not appear to have acknowledged either individually or collectively the seriousness of the situation, the expediency of cooperative political action, or the need for an integrated management system to resolve this issue. As Micklin notes:

Looking at the future, the only rational avenue for the Aral Sea Basin states to follow is cooperation and compromise in managing and sharing their transnational water resources. This is not only necessary to avoid interstate conflict, perhaps even military confrontation, but to develop an integrated basin-wide strategy to optimize water use efficiency and maximize efforts to restore and protect key water related eco-systems. ${ }^{81}$

The republics have taken tentative steps towards collective water management, although 'progress is slow and uneven, and the most critical problems remain formidable and largely unresolved'. ${ }^{82}$ Further pressures - the deterioration of the existing irrigation infrastructure, the continued economic reliance on irrigation agriculture, demographic growth, and Afghanistan's and China's demands for water, as well as non-water-related disputes suggest a heightened sense of water insecurity and an inability to cooperate. ${ }^{83}$ As a result the region's water security milieu is and will continue to be tense, although not openly hostile.

The role of external actors in this strained and confused security environment is on the whole positive but limited. Extra-regional organisations can play a useful but essentially supportive role. Encouragement and incentives for more efficient water provision, cooperative water management and conflict prevention have not necessarily found a receptive audience in Central Asia. Although the Central Asian republics have been resistant to some initiatives, 
the international community is also to blame for this failure. International organisations and individual states have failed to maintain clear and consistent objectives, with economic and strategic objectives often running counter to policies encouraging collective regional behaviour. Confusion and competition between the initiatives of different organisations have also hindered the goal of cooperative water management. ${ }^{84}$

The focus of future international attention with respect to Central Asia's water resources should include increased and simplified cooperation within the donor community and with regional bodies in order to produce a more coherent, efficient and less adversarial management structure. It should also include the provision of 'a know-how transfer concerning the legal basis of international river basins [and] the organization of water management', and induce a shift from the alleviation of the symptom (the drying up of the Aral Sea) to reform of the fundamental cause, the cultivation of cotton. Two other categories of policy response are also essential: increased support for civil society activities in general and those related to agricultural and environmental sectors in particular; and, depending upon the Central Asian states' response to the World Bank's 1996 ASBP Review, financial support. ${ }^{85}$

Interstate relations in Central Asia are far less tense than those in the Middle East, and the existing institutional framework and shared political norms at the elite level in Central Asia suggest that, while there have been disputes and tensions over water, violent conflict is unlikely. The sub-state situation has greater potential for environmentally related conflict. Here violent incidents associated with access to water have been evident, although limited in scale. The most significant of these conflicts was the 1992 'kolkhoz war' in Kurgan Teppa. ${ }^{86}$ Low-level tensions over water poaching and rerouting of irrigation canals have been reported elsewhere. ${ }^{87}$ However, these are unlikely to escalate into interstate conflict.

Although interstate conflict may be avoided, water does have wider security implications. ${ }^{88}$ The interaction between economic and environmental issues is particularly acute and problematic in the rural sector. Given the fact that the majority of the region's population is employed in the agricultural sector, this has serious implications for social stability, and possibly for security. It was reported that ecological deterioration led to the internal migration of 70,000 Kazakhstanis in $1996 .{ }^{89}$ Similarly, it is estimated that 20 per cent of agricultural jobs in Uzbekistan are superfluous. ${ }^{90}$ Degradation of agricultural land, demographic pressures, unemployment and underemployment may translate into major population movement, group competition for economic, political and social resources, social instability, the rise of political Islamist movements and the erosion of regime legitimacy. ${ }^{91}$

Given the limited scale of recent examples of water-related population and economic dislocation and instability, the security implications for the wider region and Europe in particular are limited and indirect. Also, the geographical distance between the main water flashpoints and European energy 
investments in the region and western Europe itself means that unless any potential water war escalated considerably, it would not adversely affect Western interests. However, these may be affected indirectly. Some of the interests at risk are national self-interests and material. These include risks to current and potential investments in the region, a worsening security environment in Central Asia, which could draw in significant near neighbours including Russia and China, and the possibility of massive refugee flows. Other interests are more universalist and benign in character, including the promotion and defence of human rights and conflict prevention, good governance, international and social stability, security and (sustainable) development, equitable resource allocation and environmental protection, for example. It is more likely, however, that interest in the region will be a function of narrow national interests. ${ }^{92}$

Prior to September 11 2001, western interests in the region were relatively modest. The exceptions to this rule were perhaps the concern about the Aral Sea and the investment into the energy sector. International assistance to and interest in the immediate Aral Sea region was relatively forthcoming. However, much of this was misplaced, diverting attention, energy and funding away from the fundamental causes - water mismanagement and irrigation-based cotton agriculture - to what is essentially a symptom of the basic factors. ${ }^{93}$ Since September 2001, there has been a substantive increase in western interest in the region and the resources available for implementing recent and long-term objectives there. Western European involvement in the region is more than a strategic reaction to the Americanled campaign against the Taliban regime in Afghanistan and to the American presence in Central Asia more generally. It reflects, for example, an effort to promote good governance and economic reform in the region. As a result of both self-interested and universalist objectives, it is expedient that the West retains and increases its engagement in Central Asia. Despite the difficulties faced by international institutions' activities in Central Asia, they remain probably the most effective vehicle for promoting effective regional management and European engagement on this issue. Ultimately, however, both the international donor community and the Central Asian leadership should recognise the limitations of extra-regional parties in this dynamic. The key role for 'the international donor community [is] to remind the Aral Basin governments that whereas the international community is committed to assisting the region in resolving the Aral Crises, fundamental responsibility for this rests with the Aral Sea Basin countries'. ${ }^{94}$

\section{Notes}

1 The views expressed are the author's own and should not be regarded as a statement of government or Foreign and Commonwealth Office policy. I would like to thank Sarah O'Hara and Madalene Lock for their comments on this chapter. 
2 Leigh Sarty, 'Environmental Security After Communism: The Debate', in J. DeBardeleben and J. Hannigan (eds), Environmental Security and Quality after Communism: Eastern Europe and the Soviet Successor States (Boulder, CO: Westview Press, 1995), p. 19. Environmental security, a highly contested concept, is usually applied to at least one of five spheres: (1) the environment as a cause and/or objective of conflict; (2) the environment used as an instrument of war; (3) environmental degradation resulting from military action; (4) the indirect influence of environmental degradation on security via development and welfare issues; and (5) environmental degradation and protection, distinct from its political and security implications. For a critical review of the environmental security debate, see Nils Gleditsch, 'Armed Conflict and the Environment: A Critique of the Literature', Journal of Peace Research, 35:3 (1998), pp. 381-400.

3 Thomas Homer-Dixon, 'Environmental Scarcities and Violent Conflict: Evidence from Cases', International Security, 19:1 (1994), pp. 5-40.

4 Gregory Gleason, 'The Struggle for Control over Water in Central Asia: Republican Sovereignty and Collective Action', RFE/RL Report on the USSR (21 June 1991), p. 11; and Karl Wittfogel, Oriental Despotism: A Comparative Study of Total Power (New Haven, CT: Yale University Press, 1957).

5 Hélène Carrere d'Encausse, Islam and the Russian Empire: Reform and Revolution in Central Asia (London: I. B. Tauris, 1988), p. 8.

6 See, for example, Gregory Wheeler, The Modern History of Central Asia (London: Weidenfeld and Nicolson, 1964), p. 3; Philip Micklin, Managing Water in Central Asia (London: Royal Institute of International Affairs, 2000), pp. 26-7.

7 Michael Rywkin, Moscow's Muslim Challenge: Soviet Central Asia (New York: M. E. Sharpe, 1982), p. 42.

8 Z. Goldman, 'Environmentalism and Nationalism: An Unlikely Twist in an Unlikely Direction', in John Massey Stewart (ed.), The Soviet Environment: Problems, Policies and Politics (Cambridge: Cambridge University Press, 1992), p. 9.

9 S. Abashin and V. Bushkov, Sotsial'naya napryazhennost i mezhnatsional'nye Konflikty $v$ severnykh raionah Tadjikistana, Document 24, (Moscow: IEA, 1991); Pravda, 19 July 1989; Yacoov Ro'i, 'Central Asia Riots and Disturbances, 1989-90: Causes and Context’, Central Asian Survey, 10:3 (1991), pp. 21-54, esp. p. 24.

10 See Gleason, 'Struggle for Control'; D. J. Petersen, Troubled Lands: The Legacy of Soviet Environmental Destruction (Boulder, CO: Westview Press, 1993); David R. Smith, 'Environmental Security and Shared Water Resources in Post-Soviet Central Asia', Post-Soviet Geography, 36:6 (1995), pp. 351-70. For example, see President Nursultan Nazarbaev, 'Speech at the Meeting of the Leaders of the Shanghai Cooperation Organisation States', Shanghai, China, 15 June 2001, quoted in Center for Foreign Policy and Analysis, Shanghai Cooperation Organization (Almaty: Center for Foreign Policy and Analysis, 2001), p. 7.

11 For detailed information on the rivers and the sea, see Nazarbaev, 'Speech', pp. 13-20.

12 See Sarah O'Hara, 'Water and Conflict in Central Asia', in Andrew Dobson and Jeffery Stanyer (eds), Contemporary Political Studies 1998 (Nottingham: University of Nottingham, 1998), pp. 171-9.

13 Smith, 'Environmental Security', pp. 361-2. 
14 Uzbekistan receives 38 per cent and Turkmenistan 26 per cent of the basin's total withdrawals. Kazakhstan receives 30 per cent of Syr Darya withdrawals, Tajikistan 11 per cent and Kyrgyzstan only 0.4 per cent. The Aral Sea has been allocated 16 per cent of total withdrawals. Micklin, Managing Water, pp. 46-51 and Table 5.1.

15 Ibid.

16 N. F. Vasil'yev quoted in Philip Micklin, 'The Water Crisis in Soviet Central Asia', in P. Pryde (ed.), Environmental Management in the Soviet Union (Cambridge: Cambridge University Press, 1991), p. 217; Economist Intelligence Unit, Uzbekistan Country Profile 2001 (London: EIU, 2001), p. 18; and Stefan Klötzli, The Water and Soil Crisis in Central Asia: A Source for Future Conflicts?, ENCOP Occasional Paper No. 11 (Zurich: Center for Security Policy and Conflict Research; Berne: Swiss Peace Foundation, May 1994), Table 3, on the importance of hydroelectric power in the Aral Sea basin (defined by number of power plants for differing categories of electricity production per year).

17 Gleason, 'Struggle for Control', p. 12.

18 Based on 1996 figure. Tashkent Institute of Engineers of Irrigation and Agricultural Mechanization and the Aral Sea International Committee, The Mirzaev Report (May 1998), Table 1, cited in Micklin, Managing Water, p. 68.

19 Philip Micklin, 'The Aral Sea Crisis: An Introduction to the Special Edition', PostSoviet Geography, 33:5 (1992), pp. 269-82, esp. p. 89.

20 Valery Tishkov, Ethnicity, Nationalism and Conflict: The Mind Aflame in and after the Soviet Union (London: Sage, 1997), p. 74.

21 It was renamed the Ministry of Water Management Construction (MinVodKhoz) and then restructured as a scientific research institute, in 1990. Luis Viega da Cuhna, 'The Aral Sea Crisis: A Great Challenge in Transboundary Water Resources Management', NATO Advanced Research Workshop on Transboundary Water Resources Management: Technical and Institutional Issues, Skopelos, May 1994, p. 17.

22 Inside Central Asia, 25 (31 March 1996), p. 4.

23 Viega da Cuhna, 'Aral Sea Crisis', p. 6.

24 Bruce Pannier and Edige Magauin, 'Kazakhstan: China Discusses Future of Irtysh Rivers', RFE/RL Weekly Magazine (28 May 1999); and Kazakh Commercial Television, Almaty (1300 GMT, 26 June 2001).

25 Gleason, 'Struggle for Control', p. 146; and Temirbolat Bakhytjan, 'Water Dispute Threatens Central Asian Stability: Astana is Seriously Concerned over Plans by China to Divert Several Cross-Border Rivers', Turkistan Newsletter, 4:111 (29 May 2000) www.eurasianet.org/resource/cenasia/hypermail/ 200005/0109.html.

26 See Eric Sievers, 'China Set to Divert the World's Fifth Largest River', Ecostan, 7:7 (July 2000), www.econoline.ru/news/JUN00/00062904.TXT.

27 Sarah O'Hara, 'Managing Central Asia’s Water Resources: Prospects for the 21st Century', ICREES Seminar on Environmental Issues in Central Asia, University of Nottingham, 9 December 1998, p. 13.

28 Ibid., pp. 13-14.

29 Micklin, Managing Water in Central Asia, pp. 50-1.

30 See, for example, Ibid., pp. 49-51; O’Hara, 'Managing Central Asia's Water Resources', pp. 13-14; and Smith, 'Environmental Security', p. 366. 
31 Micklin, Managing Water, p. 29.

32 Central Asia Regional Water, Environment and Energy Agreements, www.ce.utexas. edu/prof/mckinney/ce/Topics/central_asia_regional_water.htm.

33 RFE/RL Newsline, 4:112, Pt 1 (9 June 2000).

34 CAC Declaration, Article 3; and Uzbek Television, First Channel, Tashkent (1630 GMT, 28 December 2001).

35 Kazakh Commercial Television, Almaty (1130 GMT, 20 February 2002).

36 Viega da Cuhna, 'The Aral Sea Crisis', p. 13.

37 Philip Micklin, 'Regional and International Responses to the Aral Crisis', PostSoviet Geography and Economics, 39:1 (1998), pp. 399-416, esp. p. 15.

38 Micklin, Managing Water, p. 52.

39 See for example ibid., p. 46; RFE/RL Newsline, 3:104, Pt 1 (28 May 1999); and Kabar, Bishkek (1231 GMT, 13 June 2001).

40 BBC World Service (1506 GMT, 13 December 1999); RFE/RL Newsline, 4:11, Pt 1 (17 January 2000); and Inside Central Asia, 364 (26 February-4 March 2001), p. 3.

41 Inside Central Asia, 363 (19-25 February 2001), p. 3.

42 Interfax news agency, Moscow (1627 GMT, 15 February 2002); and Kazakh Commercial Television, Almaty (1130 GMT, 20 February 2002).

43 Nazarbaev, 'Speech at the Meeting of the Leaders'.

44 Kazakh Commercial Television, Almaty (1300 GMT, 26 June 2001).

45 Ibid.

46 Kazakhstan-China negotiations began in 1999. They are now in the fourth round.

47 See Declaration of Shanghai Cooperation Organization, english.peopledaily.com.cn/ 200106/15/print20010615_72738.html; and the Center for Foreign Policy and Analysis, Shanghai Cooperation Organization, pp. 9-11.

48 Micklin, Managing Water, p. 48; and Erika Weinthal, 'Making Waves: Third Parties and International Mediation in the Aral Sea Basin', in Melanie Greenberg, John Barton and Margaret McGuiness (eds), Words over War: Mediation and Arbitration to Prevent Deadly Conflict (Lanham, MD: Rowman and Littlefield, 2000), pp. 280-1.

49 Weinthal, 'Making Waves', p. 278.

50 Ibid.

51 Ibid., p. 280; and Micklin, Managing Water, p. 50.

52 Micklin, Managing Water.

53 O'Hara, 'Managing Central Asia's Water Resources', p. 15.

54 Sievers, 'China Set to Divert'.

55 Daniel Linotte, 'Water Resources Management in Central Asia: Addressing New Challenges and Risks', Analyst (15 August 2001); and Vek (6 July 2001).

56 Weinthal, 'Making Waves', p. 287.

57 Micklin, Managing Water, p. 13.

58 Kazakhstan Today, Almaty (0925 GMT, 22 October 2001).

59 Micklin, Managing Water, p. 53.

60 Owen Bowcott, 'Drought-Hit States Facing Famine', Guardian (30 October 2001).

61 BBC, 'Tajik Rebels: "We Will Blow Up Dam”' (6 November 1998).

62 Shirin Akiner, 'Conflict, Stability and Development in Central Asia', in C. J. Dick (ed.), Instabilities in Post-Communist Europe (Portsmouth: Carmichael and Sweet, 
1996), p. 14; and B. Roberts, 'More on Water in Central Asia', Cenasia. Email Discussion Group (14 April 1996).

63 OSCE, The OSCE Handbook (Vienna: OSCE, 1999), pp. 1-133. See also 'Seventh Economic Forum Focuses on "Security Aspects in the Field of the Environment", OSCE Newsletter, 6:5 (May 1999), pp. 2-3.

64 OSCE Newsletter, 6:11/12, (November-December 1999), p. 14.

65 OSCE Newsletter, 6:5 (May 1999), p. 3.

66 Hoynck quoted in 'Central Asia: New OSCE Chief. The OSCE's Role in the Region', Times of Central Asia (2 August 2001), p. 4.

67 Roy Allison, 'Central Asia: A Region in the Making', paper presented at the conference on Central Asia in a New Security Context, Swedish Institute of International Affairs, Stockholm, 2-3 September 1999, p. 9.

68 Galima Bukharbaeva, 'New Uzbek Water Crisis', Institute for War and Peace Reporting, 48 (19 April 2001).

69 Daniel Bedford, 'International Water Management in the Aral Sea', Water International, 21 (1996), pp. 63-9; and Micklin, Managing Water, p. 52.

70 The position rotates between the two presidents every two years. Karimov was eventually appointed head of the Fund in 1997. OMRI Daily Digest, 43, Pt 1 (3 March 1997).

71 S. Niyazov, Komsomolskaia Pravda (27 October 1994), quoted in Kirill Nourzhanov, 'Turkmenistan: Halfway Through to the Golden Age?', Central Asian Monitor, 1 (1995), p. 12.

72 Roland Eggleston, 'OSCE Seeks Agreement on Central Asian Water', RFE/RL Newsline, 4:110, Pt 1 ( 7 June 2000).

73 Ibid.

74 John Henning, 'Water: Potential Spark of Asian Regional Conflict', Analyst (24 May 2000), www.cacianalyst.org.

75 O'Hara, 'Water and Conflict in Central Asia', p. 21.

76 Ibid.

77 Thus, as one billboard in Karakalpakstan states, 'the catastrophy [sic] of the Aral Sea, which has shocked the entire world is an ecological disaster on a global scale which Uzbekistan and its neighbours cannot cope with alone'. See Stuart Horsman, 'Water, Security and Development in Central Asia', in EBRD (ed.), The Next Ten Years: Mapping the Challenges (London: EBRD, 2001), p. 67.

78 Linotte, 'Water Resources Management'; and Uzbek National News Agency (web site), Tashkent (9 April 2002).

79 Abdukhalil Razzakov, 'Water Shortage in Central Asia and the Re-Routing of Siberian Rivers to Central Asia', Analyst (6 June 2001), www.cacianalyst.org.

80 Thomas Naff and Ruth Matson (eds), Water in the Middle East: Conflict or Cooperation? (Boulder, CO: Westview Press, 1984), quoted in Smith, 'Environmental Security', p. 357.

81 Micklin, 'Aral Sea Crisis', p. 80.

82 Ibid.

83 Richard Dion, 'Decline of Central Asian Integration', Analyst (29 March 2000), www.cacianalyst.org.

84 See Micklin, 'The Aral Sea Crisis'; and Micklin, Managing Water in Central Asia, pp. 51-3.

85 Micklin, Managing Water, p. 49; and Weinthal, 'Making Waves'. 
86 Olivier Roy, 'Islam in Tajikistan', Project on Open Society in Central Eurasia, Occasional Paper No. 1 (New York: Open Society Institute, 1996), p. 7.

87 Personal communication with the author.

88 For a discussion of the environmental security concept and its application in Central Asia, see Stuart Horsman, 'Security Issues Facing the Newly Independent States of Central Asia: The Cases of Kazakhstan and Uzbekistan', PhD dissertation, University of Sheffield, 1999.

89 International Organization for Migration, CIS Migration Report (Geneva: IOM, 1997), pp. 56-60, cited in 'Migrations in Kazakhstan', Eurasian File, 96 (April 1998), p. 7.

90 Government of the Republic of Uzbekistan/TACIS, Uzbekistan Economic Trends 1997, First Quarter (Tashkent, 1998), p. 49.

91 For the relationship between political Islam and economic and social crises, see R. Hrair Dekmejian, 'Islamic Revival: Catalysts, Categories, and Consequences', in Shireen Hunter (ed.), The Politics of Islamic Revivalism: Diversity and Unity (Bloomington: Indiana University Press, 1988), p. 7; and James P. Piscatori (ed.), Islam in the Political Process, (Cambridge: Royal Institute for International Affairs/Cambridge University Press, 1983).

92 As Gregory Gleason states, 'The provision of assistance to Central Asia is closely related to the value that the outside world attaches [to the region and] the degree to which assistance can be expected to build long-term relationships that are valuable to the donor'. Gregory Gleason, The Central Asian States: Discovering Independence (Boulder, CO: Westview Press, 1997), p. 154.

93 Weinthal, 'Making Waves'.

94 Micklin, 'Regional and International Responses', p. 17. 